\title{
PROPERTY PRICES AND REGIONAL LABOR MARKETS IN POLAND
}

\author{
Krzysztof Drachal ${ }^{1, *}$ \\ ${ }^{1}$ Warsaw University of Technology, \\ Faculty of Mathematics and Information Science, \\ Koszykowa 75, 00-662 Warszawa, Poland
}

\begin{abstract}
:
The purpose of this research is the construction and analysis of a macroeconomic model of property prices in Poland covering the period between 2006 and 2013. The model is based on a supply-demand approach. Property prices have been found to be significantly affected by wages (positive correlation), unemployment rate (negative correlation), construction costs (positive correlation) and size of population (positive correlation). The panel data were collected from the biggest cities in voivodeships (Polish administrative regions). Both models with fixed and random effects were analyzed. Some similarities with a developed (UK) market have been found as well.
\end{abstract}

\section{Key words:}

property market, house prices, regional labor market, unemployment.

\section{INTRODUCTION}

House prices in Poland increased significantly in the period between 2002 and 2008. They increased almost 3 times in some districts. Average transaction value increased approximately 2.43 times. Only in one year period, 2005 - 2006, the prices increased by $72 \%-82 \%$ in the fastest developing cities (Florczak, 2008; Wąsewicz, 2010). Since then, a slow fall in the property prices has been observed. In some cities it was quite strong (ca. 24\%), but in the whole country, on average, it has been more stable, i.e. approximately 8\% between 2008 and 2013 (NBP, 2013). However, the Polish property market is young and still emerging. It is not as developed as Western property markets are. Not only does it lack some sophisticated instruments (for example, reverse mortgage which is still under legal discussion), but it also lacks credit boom. For example, in 2010, the value of a mortgage of an average household was only 5.5 of an average monthly salary. It is one of the lowest ratios in Europe (Drachal, 2011b; HYPO, 2010).
Moreover, official statistics (provided by the central bank) on house prices have been published recently (NBP, 2013). A lot of research has been done relying on the researchers' own data sources or on the data collected directly from developers (who do not publish their data in an easily accessible way). Therefore, the research has relied on different data sources. Moreover, there is a serious lack of econometric models for the Polish property market. Many articles are available only in Polish and they usually conclude that house prices have risen due to some social (or speculative) factors.

For example, Zelazowski (2011) constructed linear regression models for voivodeships and found that significant house price determinants are GDP per capita and population size whereas unemployment and construction costs are not that influential. Unemployment was also found not to be significant for linear regression models constructed by Drachal (2011a). Unfortunately, there has not been much research on econometric models including both property and labor markets in Poland. 
In Poland, the ratio of the people holding a university degree amongst the total labor force has a continuously rising trend. At the beginning of 2006 , there were $14.6 \%$ of university degree holders whereas currently they constitute $22.1 \%$ of the total labour force. Those holding only a high school diploma (so-called "matura" exam) maintain a stable level of $c a$. 11\%. A slight decline in the ratio of those who hold a vocational school diploma is observed. They made up $28.5 \%$ of the total labor force in 2006 and $26.3 \%$ at the beginning of 2013 (GUS, 2013). Such changes are related with the recently increased number of university degree holders in Poland who then expect to get a higher salary. Furthermore, there are plenty governmental actions focused on increasing the level of education in the Polish society. This concerns the projects which focus on the creation of innovative economy. Therefore, it may be expected that such an increase in educated labor force will drive house prices.

On the other hand, having a diploma is no longer a guarantee for having a well paid and stable job. In addition, a lot of young people have decided to immigrate since EU accession. This fact has no correspondence in official statistics, because most of them are still registered in Poland although they work and live abroad and visit their relatives in Poland just a few times a year.

The other important fact is that Polish regions (voivodeships) are highly differentiated on the basis of e.g. unemployment rate (the range in the beginning of 2013 was $11.6 \%$ ), average wages, property prices, etc. Despite the actions connected with sustainable development and attempt to compensate for these differences, the richer regions become richer and poor regions become poorer, because people move and seek jobs in richer regions or (as mentioned above) abroad. (Please note the voivodeships correspond to NUTS-2 classification.)

In view of the presented facts it seems interesting to take a closer look at the relations between the property prices and local labor markets in Poland. This paper is based on the recently published data in connection with the property market by the central bank of Poland (NBP, 2013).

\section{METHODS}

When a consumer makes a decision about buying a property it may be expected that not only the current wages, but also the perspective of future earnings are considered. Buying a property is usu- ally financed by a long term bank credit. A consumer would prefer not only to have high wages at the moment of buying, but also to keep future wages at the level allowing him to regularly repay the debt. As a result, high unemployment may be perceived as an indicator of unstable future earnings or even as a risk of losing income which allows one to afford a property. Moreover, the increasing trend of unemployment may result in stricter credit policies, which would reduce the demand for housing space (Gathergood, 2011; Johnes and Hyclak, 1999). In this particular case (the study focused on big cities) unemployment rate is one of the direct indicators of place attractiveness. A residence in an area where one may find a good job is worth more, because, for example, transportation costs are lower and one does not have to spend so much time on traveling to work every day.

One of the possible approaches towards modeling the property market is to consider supply and demand functions and to assume that the current property price is that of the partial equilibrium (Meen, 2001; Qingyu, 2010; Ashworth and Parker, 1997). One may also narrow to log-log models, i.e. the demand function is given by the equation:

(1) $\ln \left(\mathrm{h}_{\mathrm{D}}\right)=\mathrm{a}_{1} \cdot \ln (\mathrm{p})+\ln \left(\mathrm{f}\left(\mathrm{x}_{1}, \ldots, \mathrm{x}_{\mathrm{n}}\right)\right)$.

On the other hand, the supply function is given by the equation:

(2) $\ln \left(\mathrm{h}_{\mathrm{s}}\right)=\mathrm{a}_{2} \cdot \ln (\mathrm{p})+\ln \left(\mathrm{g}\left(\mathrm{y}_{1}, \ldots, \mathrm{y}_{\mathrm{m}}\right)\right)$.

In the above equations $\mathrm{a}_{1}, \mathrm{a}_{2}$ are some coefficients, $\mathrm{f}$ and $\mathrm{g}$ are some functions, $\mathrm{x}_{1}, \ldots, \mathrm{x}_{\mathrm{n}}$ are demand variables, $y_{1}, \ldots, y_{m}$ are supply variables, $h$ is available housing space and $\mathrm{p}$ is property price. Assuming the equilibrium state $\left(\right.$ i.e. $\mathrm{h}_{\mathrm{D}}=\mathrm{h}_{\mathrm{S}}$ ) and assuming particular properties for functions $\mathrm{f}$ and $\mathrm{g}$, a combination of (1) and (2) produces the following equation:

(3) $\ln \left(\mathrm{p}_{\mathrm{t}}\right)=\mathrm{b}_{0}+\mathrm{b}_{1} \cdot \ln \left(\mathrm{x}_{1, \mathrm{t}}\right)+\ldots+\mathrm{b}_{\mathrm{n}} \cdot \ln \left(\mathrm{x}_{\mathrm{n}, \mathrm{t}}\right)+\mathrm{b}_{\mathrm{n}+1}$ $\cdot \ln \left(\mathrm{y}_{1, \mathrm{t}}\right)+\ldots+\mathrm{b}_{\mathrm{n}+\mathrm{m}} \cdot \ln \left(\mathrm{y}_{\mathrm{m}, \mathrm{t}}\right)$.

In the above equation $b_{0}, b_{1}, \ldots, b_{n+m}$ are some coefficients and $t$ indicates time period.

The wages and their first lags (first differences), new available housing space, population size, unemployment rate, ratio of high skilled workers in total labor force, size of the total labor force, construction costs and mortgage rate were chosen as potentially significant factors determining demand and supply. Such a choice is consistent with the research mentioned previously and with the stated hypotheses about Polish property market. 
Property prices, wages, new housing space and ratio of skilled workers have log-normal distribution assuming 5\% significance level. Nevertheless, $\log$-log models are useful if distribution is long right tailed (as - roughly speaking - it is in the considered case). They also work well when operations are rather multiplicative than additive. At least log-log models are often used in estimating demand functions, when constant elasticity is desired (Hill et al., 2011). For example, a similar model was used by Qingyu (2010) in case of the UK property market. Therefore, it would be also useful to compare the results between the UK and Poland obtained from similar models in the further part of this paper.

Quarterly data covering the period starting in the third quarter of 2006 and ending in the first quarter of 2013 were taken. The data for 16 biggest cities were collected, one city from each Polish voivodeship. The obtained panel is balanced. The official statistics from the National Statistics Bureau and central bank were used (GUS, 2013; NBP, 2013). Unfortunately, there is no reliable data source containing the property prices in Poland which would cover the period before 2006 .

All data, except construction costs (in PLN) and mortgage rates (in \%), were collected only for particular cities (not for the whole regions these cities represent). It is reasonable to assume that they are the same for all voivodeships. Wages (in PLN) were measured as an average monthly wage. It has to be mentioned that wages in Poland are highly differentiated. This may influence the usability of an average wage as a ratio. However, it is the best indicator of consumer wealth, if one does not want to divide consumers into more specific groups. New available housing space was measured in square meters, this concerns the housing buildings finished in the considered quarter. Population size (of the cities) was measured by the number of people who are permanently registered to live there. This number may not correspond to reality, because big cities in voivodeships usually provide jobs for people who are officially registered in other voivodeships. However, if one buys a house or flat, he or she must be registered to live in such a house or flat. On the other hand, if someone buys a few flats and rents them to people who are officially registered somewhere else then in such a case there is no correspondence in the official statistics. This fact may be potentially an important bias in case of e.g. Warsaw (the capital city). Unfortunately, more thorough data about the mentioned case would require another specific research. Adding a variable corresponding to the number of workers to the model is one of the possible remedies. Unemployment rate is measured in percentages. Ratio of skilled workers is measured as a percentage of those people who hold a university diploma amongst the total labor force.

Mortgage rates and housing prices were taken from the central bank statistics (NBP, 2013). All other data were taken from the National Statistics Bureau (GUS, 2013).

Historically, the most important problem in any analysis of the Polish property market has been a complete lack of the official house price index. Research was based on different data sources originating from different providers. Sometimes even construction costs were misleadingly used. (It occurred in some non-Polish research, probably due to translational problems.) Fortunately, the central bank has published some data from its own sources recently. It can be perceived as a highly reliable source and detailed enough in order to proceed with the analysis. The analysis is based on transactional prices.

Calculations are done with the help of GRETL package.

\section{CALCULATION AND RESULTS}

One possible model when working with panel data is that of fixed effects. In such a model it is assumed that the relationships between predictors and the outcome variable are characteristics of each voivodeship. Variables vary with time and these characteristics are assumed to be unique for particular voivodeships and constant with time.

A random effects model is proper if one assumes that differences across voivodeships have some influence on explanatory variables. It seems reasonable that such a thing happens for the analyzed data. Moreover, results of a random effects model may be generalized for the whole population (in the considered case: big cities in Poland). On the other hand, the sample taken into the analysis (the biggest city from each voivodeship) is complete if the population is considered to be the biggest voivodeship cities. The sample is relatively small, if the population is understood as just these big Polish cities (without much precision what "big" means). Therefore, random model effect may be extrapolated on big Polish cities in general. But a question emerges - can the other big cities be classified in the same cluster as capitals of voivodeships? 
SJAS 2014 \& $11(1) \diamond 5-15$

Drachal K. \& Property prices and regional labor markets in Poland

\begin{tabular}{cccccccc}
\hline model & const & $\ln \left(\right.$ hspace $\left._{\mathrm{t}}\right)$ & $\ln \left(\right.$ unemp $\left._{\mathrm{t}}\right)$ & $\ln \left(\right.$ costs $\left._{\mathrm{t}}\right)$ & $\ln \left(\right.$ wages $\left._{\mathrm{t}-1}\right)$ & $\ln \left(\right.$ psize $\left._{\mathrm{t}}\right)$ & Adj. R2 \\
\hline FE & $6.661^{* *}$ & $-0.01756^{* *}$ & $-0.2506^{* *}$ & $0.1044^{* *}$ & $0.1903^{* *}$ & & 0.9179 \\
& $(0.2978)$ & $(0.008474)$ & $(0.01810)$ & $(0.04226)$ & $(0.06245)$ & & \\
\hline \multirow{2}{*}{$\mathrm{RE}$} & $4.081^{* *}$ & & $-0.2417^{* *}$ & $0.09668^{* *}$ & $0.2003^{* *}$ & $0.1850^{* *}$ & \\
& $(0.8025)$ & & $(0.01751)$ & $(0.04189)$ & $(0.06171)$ & $(0.06020)$ & \\
\hline
\end{tabular}

Table 1: Panel regressions estimations.

Dependent variable: $\ln (p t)$

Standard errors in parentheses

** indicates significance at the 5 percent level

Therefore, both models were evaluated. Table 1 presents the outcomes from panel regressions.

It appears that only housing space (hspace), unemployment rate (unemp), construction costs (costs) and wages (wages) are significant for the fixed effects model. For a random effects model housing space is not significant, but population size (psize) is significant (contrary to fixed effects model). All signs of coefficients in both models are consistent with economics theory prediction. Moreover, coefficients for common significant variables in both models are almost the same numerically. (For detailed outcomes see Appendix 2.)

Due to Hausman test the random effects model is preferred. Similar conclusion is taken from BreuschPagan test. But the problem may be that for a random effects model it is assumed that unobserved variables are uncorrelated with all observed variables. From econometric point of view more detailed tests would be more useful then. However, the presented analysis is a pioneering one for the current Polish market, so only the first outcomes are communicated here.

The next problem is to estimate regressions for each voivodeship. This is to find out whether the house prices are more sensitive to unemployment rate in richer regions (i.e. characterized by higher average wages throughout the whole analyzed period). The outcomes of (robust, HAC) regression are presented in Table 2. (see Appendix 1. for the abbreviated names of voivodeships).

The increase in unemployment rate results in the decrease in house prices in all regions. However, the differences in elasticity are high between voivodeships. For example, in the most developed region (MA), characterized by the highest average wages, house prices are sensitive to unemployment at the moderate level in comparison with other regions. It can be seen from Picture 1 that there are a few groups of regions. The first one (including only MA) is characterized by high wages and moderate sensitivity to unemployment. The second group (including MP and DS) consists of regions with small sensitivity to unemployment and moderate average wages. These regions are the developed ones. For example, DS is attractive for large business. MP is not only business friendly, but also attractive for tourists. The third group (including only WM) consists of the region with small unemployment sensitivity and low average wages. This is the region with high unemployment rate, but very attractive for tourists. However, it lacks good road connections. The fourth group (including $\mathrm{OP}, \mathrm{WP}$ and $\mathrm{ZP}$ ) consists of regions with lower wages and it is moderately sensitive to unemployment. The fifth group (including PM and SL) consists of regions with higher average wages and there is a moderate unemployment sensitivity. These regions are the centers of large businesses. For example, SL is heavily urbanized (mostly because of heavy industry, mines, etc.). The sixth group (including $\mathrm{PK}, \mathrm{LB}, \mathrm{PD}, \mathrm{LD}$ and $\mathrm{KP}$ ) consists of regions characterized by lower wages and higher sensitivity to unemployment. The last group (including LU and SW) consists of regions with low wages and very high sensitivity to unemployment. These regions are not developed and there are more developed or more tourist attractive regions in their neighborhood.

Summarizing, it cannot be stated that the house prices in poorer regions are the ones less sensitive to unemployment rate changes. The sensitivity to unemployment is rather connected with opportunities of each region and its potential to continue the existing development processes in the future. If a region has some characteristics which increase its long term opportunities for a potential investor (e.g. tourist attractiveness, concentration of heavy industry, headquarters of large companies, etc.) then, even if wages are high, house prices are not sensitive to unemployment 


\begin{tabular}{|c|c|c|c|c|c|c|}
\hline voivodeship & const & $\ln \left(\right.$ unemp $\left.p_{t}\right)$ & $\ln \left(\right.$ costs $\left._{t}\right)$ & $\ln \left(\right.$ wages $\left._{t-1}\right)$ & $\ln \left(\right.$ psize $\left._{t}\right)$ & R2 \\
\hline \multirow[t]{2}{*}{ PD } & $205.5^{* *}$ & $-0.3810 * *$ & $0.2599 * *$ & $0.3288^{* *}$ & $-15.96 * *$ & 0.6466 \\
\hline & $(1.253 e-05)$ & $(2.284 \mathrm{e}-09)$ & $(6.235 e-09)$ & $(2.852 \mathrm{e}-09)$ & (9.930e-07) & \\
\hline \multirow[t]{2}{*}{$\mathrm{KP}$} & $-7.547^{* *}$ & $-0.4384 * *$ & $0.3772 * *$ & $0.1500 * *$ & $0.9622 * *$ & 0.5722 \\
\hline & $(5.368 \mathrm{e}-09)$ & $(8.952 \mathrm{e}-012)$ & (6.510e-013) & $(3.085 e-012)$ & $(4.193 e-010)$ & \\
\hline \multirow[t]{2}{*}{ PM } & $3.152 * *$ & $-0.2393 * *$ & $0.1852 * *$ & $0.01607 * *$ & $0.3211 * *$ & 0.5354 \\
\hline & $(1.605 e-08)$ & $(1.122 \mathrm{e}-011)$ & (9.184e-012) & (2.010e-011) & $(1.251 \mathrm{e}-09)$ & \\
\hline \multirow[t]{2}{*}{ SL } & $-15.38 * *$ & $-0.2934 * *$ & $0.1634^{* *}$ & $0.4076^{* *}$ & $1.521 * *$ & 0.6040 \\
\hline & (7.550e-09) & (3.910e-012) & (7.696e-012) & (3.615e-011) & $(5.791 \mathrm{e}-010)$ & \\
\hline \multirow[t]{2}{*}{ SW } & $3.386 * *$ & $-0.8966 * *$ & $0.3296 * *$ & $0.1559 * *$ & $0.2491^{* *}$ & 0.7451 \\
\hline & $(5.963 e-09)$ & $(8.293 e-012)$ & $(3.534 \mathrm{e}-013)$ & $(3.768 \mathrm{e}-011)$ & $(4.618 \mathrm{e}-010)$ & \\
\hline \multirow[t]{2}{*}{ MP } & $-146.1^{* *}$ & $-0.07894 * *$ & $-0.1281^{* *}$ & $-0.1843^{* *}$ & $11.63^{* *}$ & 0.4931 \\
\hline & $(5.816 e-06)$ & $(1.603 e-09)$ & $(2.210 \mathrm{e}-09)$ & (6.291e-09) & $(4.322 \mathrm{e}-07)$ & \\
\hline \multirow[t]{2}{*}{ LU } & $195.7^{* *}$ & $-0.6237 * *$ & $0.2390 * *$ & $0.06433 * *$ & $-14.76 * *$ & 0.8292 \\
\hline & $(7.608 \mathrm{e}-07)$ & (7.076e-011) & $(1.788 \mathrm{e}-010)$ & (1.926e-09) & $(5.826 e-08)$ & \\
\hline \multirow[t]{2}{*}{ LD } & $-2.897^{* *}$ & $-0.4307 * *$ & $0.05962 * *$ & $0.4718^{* *}$ & $0.5793^{* *}$ & 0.4260 \\
\hline & $(1.593 \mathrm{e}-08)$ & $(2.067 \mathrm{e}-011)$ & (1.506e-011) & $(1.191 \mathrm{e}-010)$ & (1.096e-09) & \\
\hline \multirow[t]{2}{*}{ WM } & $1.558 * *$ & $-0.2086 * *$ & $0.1155^{* *}$ & $0.09816 * *$ & $0.4548 * *$ & 0.4961 \\
\hline & $(5.338 \mathrm{e}-08)$ & (3.295e-011) & $(6.882 \mathrm{e}-011)$ & (4.960e-011) & (4.429e-09) & \\
\hline \multirow[t]{2}{*}{$\mathrm{OP}$} & $45.43^{* *}$ & $-0.2681 * *$ & $-0.09801 * *$ & $0.02086^{* *}$ & $-3.076 * *$ & 0.5371 \\
\hline & (6.209e-09) & (1.507e-011) & $(2.126 \mathrm{e}-012)$ & (6.952e-011) & $(4.779 \mathrm{e}-010)$ & \\
\hline \multirow[t]{2}{*}{ WP } & $-172.1^{* *}$ & $-0.2344 * *$ & $-0.07544^{* *}$ & $1.108^{* *}$ & $13.05^{* *}$ & 0.5560 \\
\hline & $(1.433 e-06)$ & (7.486e-011) & $(1.510 \mathrm{e}-010)$ & (6.571e-09) & $(1.042 \mathrm{e}-07)$ & \\
\hline \multirow[t]{2}{*}{ PK } & $-26.72 * *$ & $-0.4258 * *$ & $-0.2500 * *$ & $0.04400 * *$ & $3.116 * *$ & 0.6100 \\
\hline & (4.157e-09) & $(1.736 \mathrm{e}-011)$ & $(1.447 e-011)$ & (9.192e-011) & $(4.176 e-010)$ & \\
\hline \multirow[t]{2}{*}{ ZP } & $-45.98^{* *}$ & $-0.2753 * *$ & $0.2022^{* *}$ & $-0.06378^{* *}$ & $4.161^{* *}$ & 0.7529 \\
\hline & $(2.978 \mathrm{e}-09)$ & $(2.648 \mathrm{e}-012)$ & (8.647e-012) & (1.609e-011) & $(2.264 \mathrm{e}-010)$ & \\
\hline \multirow[t]{2}{*}{ MA } & $159.4^{* *}$ & $-0.2330 * *$ & $-0.01948^{* *}$ & $-0.1004 * *$ & $-10.39 * *$ & 0.7120 \\
\hline & $(5.864 \mathrm{e}-07)$ & $(1.737 e-010)$ & $(8.104 \mathrm{e}-010)$ & $(1.502 \mathrm{e}-09)$ & $(4.126 e-08)$ & \\
\hline \multirow[t]{2}{*}{ DS } & $289.9 * *$ & $-0.1147 * *$ & $0.03252 * *$ & $-0.5534 * *$ & $-20.73 * *$ & 0.3043 \\
\hline & $(2.833 e-05)$ & $(2.128 \mathrm{e}-09)$ & $(1.621 \mathrm{e}-08)$ & $(1.375 e-08)$ & $(2.103 e-06)$ & \\
\hline \multirow[t]{2}{*}{ LB } & $-49.99 * *$ & $-0.3864 * *$ & $-0.1812 * *$ & $0.3265^{* *}$ & $4.938 * *$ & 0.3922 \\
\hline & $(1.469 \mathrm{e}-08)$ & $(2.466 \mathrm{e}-011)$ & (7.483e-012) & (3.851e-011) & $(1.293 e-09)$ & \\
\hline
\end{tabular}

Table 2: Regression estimates.

Dependent variable: $\ln (p t)$

Standard errors in parentheses

** indicates significance at the 5 percent level 


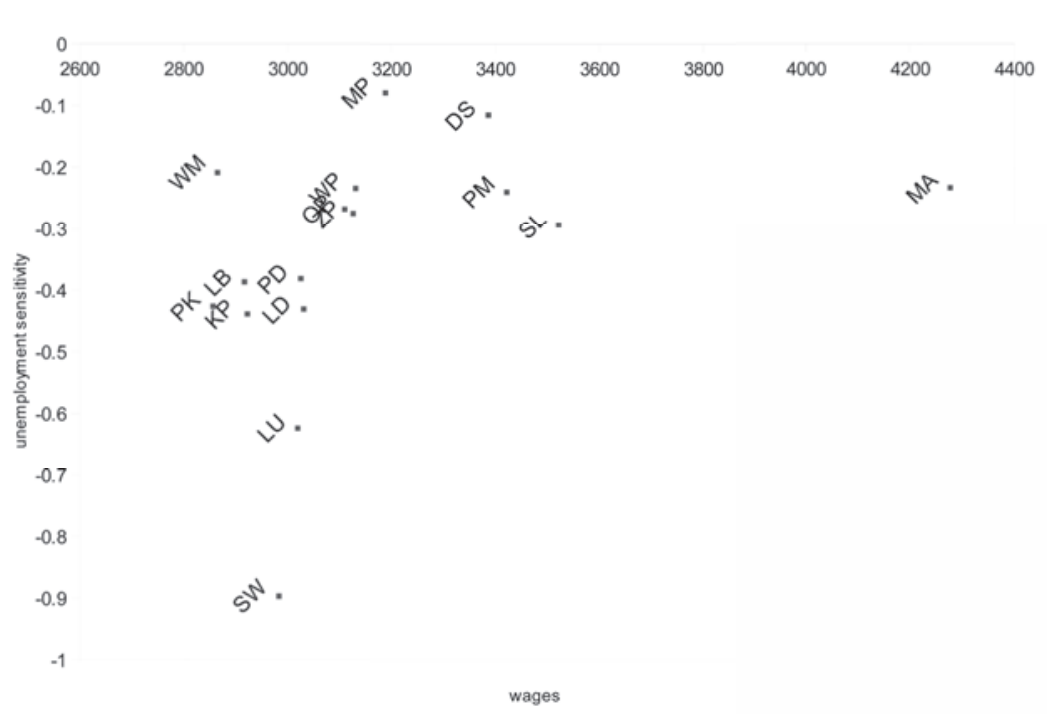

Picture 1: Coefficient of $\ln \left(\right.$ unemp $\left._{t}\right)$ vs. average wage.

changes more than the whole country on average. However, if there are fast developing, more attractive regions around or if a region is generally perceived as underdeveloped, then such a region is highly sensitive to unemployment rate changes.

The average is taken from the whole period between the third quarter of 2006 and the first quarter of 2013.

It has been found that unemployment rate and ratio of people holding a university diploma are not significantly correlated. However it may be easily observed that there is a significant positive correlation between property prices and level of average wages.

Although it has been stated that sensitivity of prices to unemployment is not observed to be higher in richer regions, it can be seen that unemployment rate is negatively correlated with prices. It is another argument in favor of hypothesis that one of the important determinants driving the property prices in big Polish cities is a low unemployment rate.

Finally, notice that generally there is a negative "relationship" between mortgage rate and unemployment rate. However, Philips curve analogy is too simple. (Remember e.g. that unemployment varies through regions, but mortgage rate is the same for the whole country). On the other hand, the wage curve behaves normally. In other words, regions of high unemployment are characterized by low average wages and vice versa.

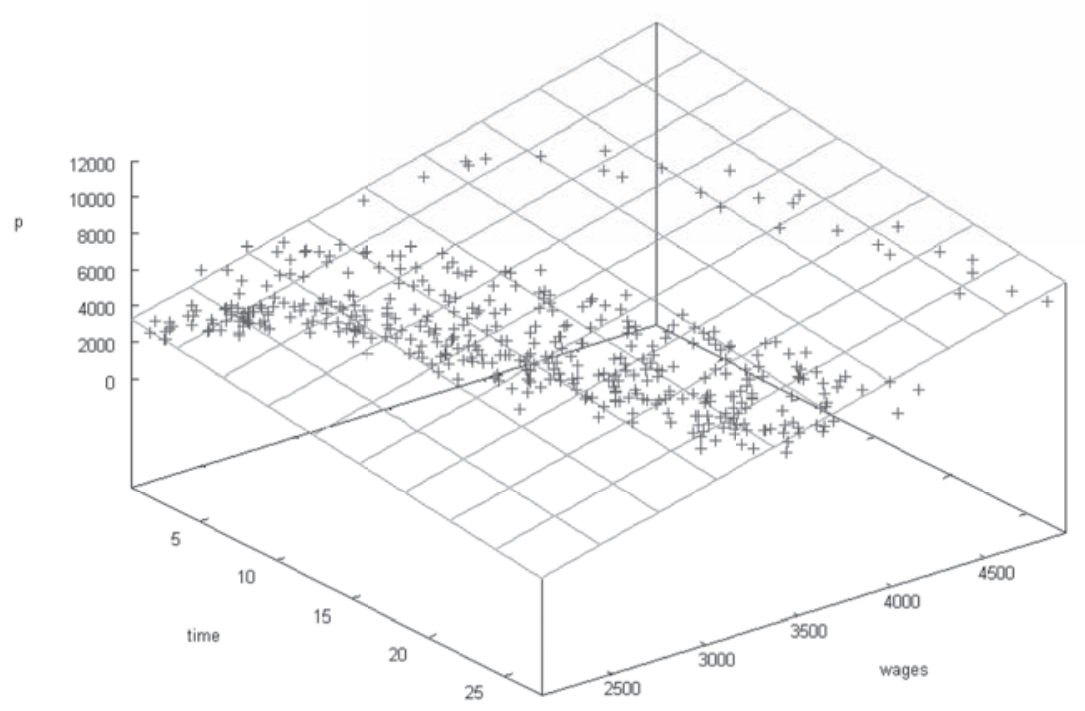

Picture 2: Property prices and average wages for each voivodeship between 2006 and 2013. 


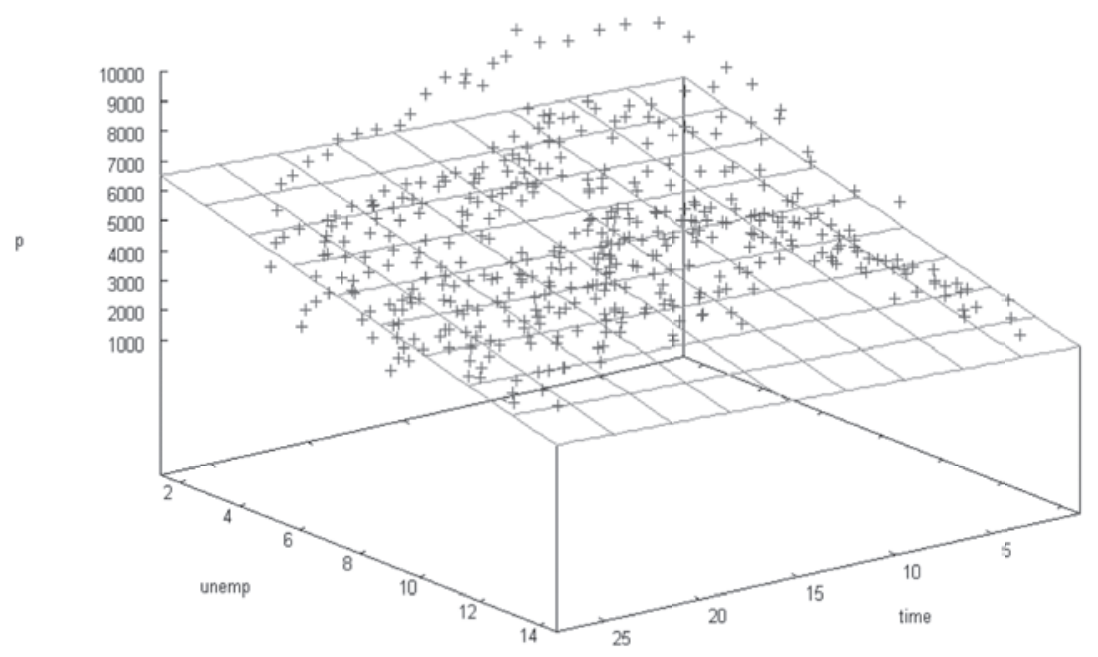

Picture 3: Property prices and unemployment rate for each voivodeship between 2006 and 2013.

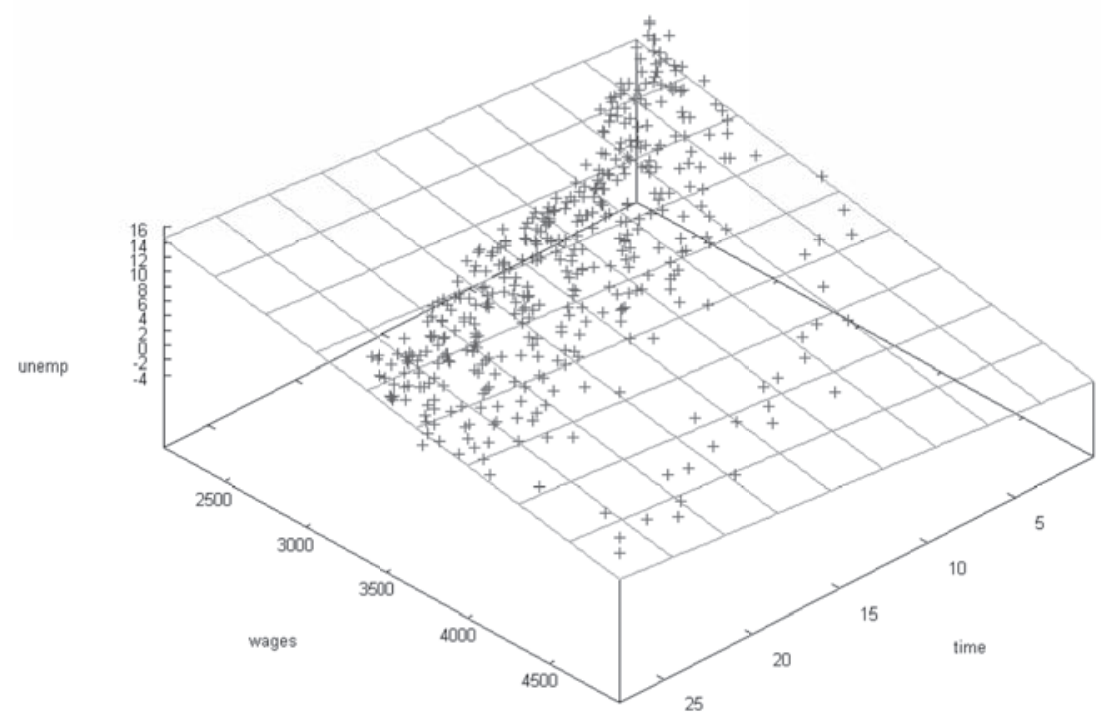

Picture 4: Average wages and unemployment rate for each voivodeship between 2006 and 2013.

\section{DISCUSSION AND CONCLUSIONS}

Out of Central and Eastern European markets, the Polish real estate market is the one most correlated with the UK market (Kucharska-Stasiak, Matysiak, 2004). Furthermore, it is the fastest developing economy in the European Union and the Polish property market is the most active one out of other Central and Eastern European markets (PWC, 2013). On the other hand, the UK property market is more developed and bigger. Moreover, in Poland only $8.4 \%$ of the population lives in their own prop- erty burdened with a mortgage or loan, whereas in the UK it is $41.9 \%$. In Poland $73.7 \%$ of the population lives in their own property with no outstanding mortgage or housing loan, whereas in the UK it is only 26\% (EUROSTAT, 2013). But transparency of Polish real estate market is comparable with Western developed markets. Some investors perceive the Polish market even as the "core" one. The UK market transparency gained 1.33 composite score and is therefore the second most transparent market in the world (and therefore the first one amongst European countries, too). Poland gained 2.11 composite 
scores and is on the 19th place in the world, according to Jones Lang LaSalle report (2012). Therefore, it is interesting to compare the results of the current research for Poland with the similar surveys for the UK.

For example, it is interesting that for a similar logarithmic model almost the same value of $\mathrm{R}$-squared coefficient has been found on the UK market when the fixed effects model was analyzed (Qingyu, 2010). However, in case of Poland only the first lag of wages is significant, whereas for the UK current wages have also been found significant. Moreover, on the UK market, it has been observed that interest rates have a significant influence on house prices. A very astonishing fact is that the average sensitivity of unemployment rate is almost the same in Poland and in the UK. Moreover, similar numerical values of regional sensitivity have been found in Poland and the UK for different regions (similar ranges). In both Poland and the UK very small and very high values of this sensitivity have been found. On the contrary, Qingyu (2010) has found results from the UK inconclusive to determine whether poorer regions are more sensitive to unemployment rate changes. On the other hand, Meen (2001) concluded that such correlation exists indeed. Also Clapp and Giacotto (1994) found such relationship important in the US and Vermeulen (2008) in some Western European cities.

In the final random effects model, a mortgage rate has not been included. However, regression models for each voivodeship allow inserting a mortgage rate into models for most cities (except for just a few ones). However, after that R-squared of models has not been much greater than the original ones (presented in Table 2). In addition, coefficients for other variables do not change significantly after including a mortgage rate, therefore, omitting this variable does not generate much bias. In fact, it may occur that the real impact of interest rate is "included" in wages. Consumers may perceive interest costs not by direct evaluation but by perception of their wealth just through wages.

In Poland it has been found that house prices are significantly more sensitive to unemployment than on average only in two highly underdeveloped and poor regions (out of sixteen analyzed regions). It is worth mentioning that there are also a few relatively rich regions, where changes in unemployment have only a slight influence on house prices. It seems that in Poland there are regional characteristics that influence house prices, not simply the current unemployment rate level.
Regression models for each voivodeships have much smaller R-squared than similar ones for the UK. It is consistent with the previous research (unfortunately available only in Polish) concluding that it is hard to model house prices solely on the basis of macroeconomic indicators. However, the obtained R-squared seems satisfactory for many regions, confirming that the model proposed in this paper is usable.

At first, it was expected that an increasing rate of the people who hold university diplomas would play significant role in house price increase. Such expectations were justified as they relied on the research from other countries, e.g. Glaeser and Saiz (2003) or Andrews and Sanchez (2011). However, this has not been confirmed by the conducted analysis. Maybe some other models will say more about the relationship between the house prices and education in Poland. It has thus far remained an open question.

If one assumes that differences between voivodeships change with time, then it is reasonable to stick to a random effects model. It may be stated further (but still as a hypothesis open for future research) that the house price dynamics in the biggest cities is a consequence of continuous adaptation of labor force. In other words, current social-economical processes lead to a situation in which more and more people work (and therefore live) in big cities. Small cities are becoming less attractive, because they offer fewer opportunities in comparison with large city agglomerations. Regional labor markets polarization has been observed in Europe e.g. by Puga and Overman (2002). What drives the house prices in big cities may not only be the current macroeconomic situation, but also the possibility to gain profits in the future. Profits from having closer distance to good schools for children, well equipped medical centers, possibility to rent rooms for students or workers, etc. If the number of workers who hold a university diploma increases, then employers will consequently increase their recruitment requirements, especially in big cities.

Therefore (in further research) it would be interesting to consider some other models including, for example, the time needed to find a job, the time spent on traveling to work, access to medical centers, training centers, schools and universities, number of theaters, cinemas, community centers, and other factors connected with the standard of living and its changes in the selected cities. 


\section{REFERENCES}

Andrews, D., \& Sanchez, A.C. (2011). Drivers of homeownership rates in selected OECD countries. doi: $10.1787 / 5 \mathrm{kgg} 9 \mathrm{mcwc} 7 \mathrm{jf}-\mathrm{en}$.

Ashworth, J., \& Parker, S.C. (1997). Modelling regional house prices in the UK. Scottish Journal of Political Economy, 44(3), 225-246. doi: 10.1111/14679485.00055.

Clapp, J.M., \& Giacotto, C. (1994). The influence of economic variables on house price dynamics. Journal of Urban Economics, 36(2), 161-183. doi: 10.1006/ juec.1994.1031.

Drachal, K. (2011a). Analiza determinant cen nieruchomości w Polsce. Świat Nieruchomości, 75, 30-33. (in Polish).

Drachal, K. (2011b). Perspektywa polskiego rynku nieruchomości. Świat Nieruchomości, 78, 10-15. (in Polish).

EUROSTAT. (2013). Housing statistics. Retrieved August 1, 2013, from http://epp.eurostat.ec.europa.eu/ statistics_explained/index.php/Housing_statistics.

Florczak, K. (2008). Ceny na polskim rynku nieruchomości mieszkaniowych. Studia i Materiały Towarzystwa Naukowego Nieruchomości, 16(2), 33-44. (in Polish).

Gathergood, J. (2011). Unemployment risk, house price risk and the transition into homeownership in the United Kingdom. Journal of Housing Economics, 20(3), 200-209. doi: 10.1016/j.jhe.2011.03.001.

Glaeser, E.L., \& Saiz, A. (2003). The rise of the skilled city. Retrieved August 20, 2013, from http://www.philadelphiafed.org/research-and-data/publications/working-papers/2004/wp04-2.pdf.

GUS. (2013). Statistical yearbook of the Republic of Poland 2013. Retrieved August 21, 2013, from http:// www.stat.gov.pl/cps/rde/xbcr/gus/RS_rocznik_statystyczny_rp_2013.pdf.

Hill, R.C., Griffiths, W.E., \& Lim, G.C. (2011). Principles of econometrics. New York: Wiley.

HYPO. (2010). Hypostat 2010: A review of Europe's mortgage and housing markets. Retrieved September 2, 2013, from http://www.hypo.org/Content/default.asp?pageId=578.
Drachal K. $\diamond$ Property prices and regional labor markets in Poland

Johnes, G., \& Hyclak, T. (1999). House prices and regional labor markets. The Annals of Regional Sciences, 33(1), 33-49. doi: 10.1007/s001680050091.

Jones Lang LaSalle. (2012). Real estate transparency index. Retrieved November 4, 2013, from www.lasalle. com/Research/ResearchPublications/TransparencyIndex_2012.pdf.

Kucharska-Stasiak, E., \& Matysiak, G. (2004). The transition of the Polish real estate market within a Central and Eastern European context. Retrieved September 12, 2013, from http://www.reading.ac.uk/LM/LM/ fulltxt/1604.pdf.

Meen, G. (2001). The time-series behavior of house prices: A transatlantic divide? Journal of Housing Economics, 11(1), 1-23. doi: 10.1006/jhec.2001.0307.

NBP. (2013). Ceny ofertowe. Retrieved September 12, 2013, from http://www.nbp.pl/publikacje/rynek_nieruchomosci/ceny_mieszkan.xls. (in Polish).

Puga, D., \& Overman, H.G. (2002). Unemployment clusters across Europe's regions and countries. Economic Policy, 17(34), 115-147. doi: 10.1111/1468-0327.00085.

PWC. (2013). Emerging trends in real estate. Survey of $P w C$ and Urban Land Institute. Retrieved November 4, 2013, from http://www.uli.org/wp-content/uploads/ ULI-Documents/Emerging-Trends-Europe-2013.pdf.

Qingyu, Z. (2010). Regional unemployment and house price determination. MPRA Paper No. 41785. Retrieved September 2, 2013, from http://mpra.ub.uni-muenchen.de/41785/.

Vermeulen, W. (2008). Essays on housing supply, land use regulation and regional labour markets. [Amsterdam]: Thela Thesis.

Wąsewicz, M. (2010). Rynek nieruchomości mieszkaniowych i jego finansowanie. Annales Universitatis Mariae Curie-Sklodowska, 44, 553-566. (in Polish).

Żelazowski, K. (2011). Regionalne zróżnicowanie cen i ich determinant na rynku mieszkaniowym w Polsce. Studia i Materialy Towarzystwa Naukowego Nieruchomości, 19(3), 98-106. (in Polish). 


\section{APPENDIX 1}

\section{Abbreviations of voivodeships:}

DS - Lower Silesian,

KP - Kuyavian-Pomeranian,

LB - Lubusz,

LD - Lodz,

LU - Lublin,

MA - Masovian,

MP - Lesser Poland,

OP - Opole,

PD - Podlaskie,

PK - Subcarpathian,

PM - Pomeranian,

SL - Sielsian,

SW - Swietokrzyskie,

WM - Warmian-Masurian,

WP - Greater Poland,

ZP - West Pomeranian.

\section{APPENDIX 2}

\section{FE:Fixed-effects, using $\mathbf{4 1 6}$ observations}

Included 16 cross-sectional units

Time-series length $=26$

Dependent variable: $\ln \_p$

\begin{tabular}{lccccc}
\hline & Coefficient & Std. Error & t-ratio & $p$-value \\
\hline const & 6.66134 & 0.297761 & 22.3714 & $<0.00001$ & $* * *$ \\
\hline In_hspace & -0.0175582 & 0.00847371 & -2.0721 & 0.03890 & $* *$ \\
\hline In_unemp & -0.250556 & 0.0181032 & -13.8404 & $<0.00001$ & $* * *$ \\
\hline In_costs & 0.104383 & 0.0422579 & 2.4701 & 0.01393 & $* *$ \\
\hline In_wages_1 & 0.190334 & 0.0624463 & 3.0480 & 0.00246 & $* * *$ \\
\hline
\end{tabular}

\begin{tabular}{lc}
\hline Mean dependent var & 8.409087 \\
\hline Sum squared resid & 2.303636 \\
\hline R-squared & 0.921628 \\
\hline F(19, 396) & 245.0973 \\
\hline Log-likelihood & 490.5304 \\
\hline Schwarz criterion & -860.4472 \\
\hline rho & 0.507505 \\
\hline
\end{tabular}

\begin{tabular}{lc}
\hline S.D. dependent var & 0.266136 \\
\hline S.E. of regression & 0.076271 \\
\hline Adjusted R-squared & 0.917868 \\
\hline P-value(F) & $1.9 \mathrm{e}-205$ \\
\hline Akaike criterion & -941.0609 \\
\hline Hannan-Quinn & -909.1864 \\
\hline Durbin-Watson & 0.667184 \\
\hline
\end{tabular}

\section{Test for differing group intercepts -}

Null hypothesis: The groups have a common intercept

Test statistic: $\mathrm{F}(15,396)=85.7876$

with $\mathrm{p}$-value $=\mathrm{P}(\mathrm{F}(15,396)>85.7876)=3.50401 \mathrm{e}-114$ 


\section{RE:Random-effects (GLS), using $\mathbf{4 1 6}$ observations}

Included 16 cross-sectional units

Time-series length $=26$

Dependent variable: ln_p

\begin{tabular}{cccccc}
\hline & Coefficient & Std. Error & t-ratio & $p$-value & \\
\hline const & 4.08112 & 0.802456 & 5.0858 & $<0.00001$ & $* * *$ \\
\hline I_households & 0.185023 & 0.0601992 & 3.0735 & 0.00226 & $* * *$ \\
\hline I_unemp & -0.241658 & 0.0175068 & -13.8036 & $<0.00001$ & $* * *$ \\
\hline I_costs & 0.0966763 & 0.0418942 & 2.3076 & 0.02152 & $* *$ \\
\hline I_wages_1 & 0.200324 & 0.0617083 & 3.2463 & 0.00126 & $* * *$ \\
\hline
\end{tabular}

\begin{tabular}{ll}
\hline Mean dependent var & 8.409087 \\
\hline Sum squared resid & 11.75969 \\
\hline Log-likelihood & 151.4511 \\
\hline Schwarz criterion & -272.7488 \\
\hline
\end{tabular}

\begin{tabular}{lc}
\hline S.D. dependent var & 0.266136 \\
\hline S.E. of regression & 0.168947 \\
\hline Akaike criterion & -292.9023 \\
\hline Hannan-Quinn & -284.9337 \\
\hline
\end{tabular}

'Within' variance $=0.00587845$

'Between' variance $=0.0291888$

theta used for quasi-demeaning $=0.911989$

\section{Breusch-Pagan test -}

Null hypothesis: Variance of the unit-specific error $=0$

Asymptotic test statistic: Chi-square(1) $=3202.49$

with $\mathrm{p}$-value $=0$

\section{Hausman test -}

Null hypothesis: GLS estimates are consistent

Asymptotic test statistic: Chi-square $(4)=0.487165$

with $\mathrm{p}$-value $=0.974738$

\section{CENE NEKRETNINA I REGIONALNA TRŽIŠTA RADA U POLJSKOJ}

\section{Rezime:}

Cilj ovog istraživanja je izrada i analiza makroekonomskog modela cena nekretnina u Poljskoj u periodu između 2006. i 2013. godine. Model je zasnovan na pristupu ponuda - potražnja. Konstatovano je da na cene nekretnina značajno utiču plate (pozitivna korelacija), stopa nezaposlenosti (negativna korelacija), troškovi izgradnje (pozitivna korelacija) i broj stanovništva (pozitivna korelacija). Podaci su prikupljeni iz najvećih gradova u vojvodinama (administrativnim regioni na koje je podeljena Poljska). Analizirana su oba modela sa fiksnim i slučajnim efektima. Konstatovane su takođe i neke sličnosti sa razvijenim tržištima (UK).

Ključne reči:

tržište nekretnina, cene stambenih jedinica, regionalno tržište rada, nezaposlenost

Received: October 10th, 2013. Correction: October 31st, 2013. Accepted: November 12th, 2013. 